\title{
Isolation and longterm culture of human intestinal microvascular endothelial cells
}

\author{
G Haraldsen, J Rugtveit, D Kvale, T Scholz, W A Muller, T Hovig, P Brandtzaeg
}

\begin{abstract}
Microvascular endothelial cells play an important part in inflammation as well as in organ specific leucocyte traffic, and may be functionally different from large vessel endothelium in this respect. This study therefore established a method for isolation and longterm culture of human intestinal microvascular endothelial cells (HIMEC). After dissociation by collagenase/dispase/DNase of mucosal and submucosal tissue obtained from normal adult jejunum, cells were plated and cultured to subconfluence in endothelial serum free medium containing $2 \cdot 5 \%$ fetal calf serum, hydrocortisone, and $\mathbf{N}^{6}, \mathbf{O}^{2}$-dibutyryladenosine cyclic monophosphate. Primary cultures were trypsinised and endothelial cells were isolated by paramagnetic beads armed with monoclonal antibody to CD31. Optimal growth conditions for HIMEC cultures were established, allowing up to nine passages (three months in vitro). The cells contained Weibel-Palade bodies, expressed von Willebrand factor, CD31, and VE-cadherin; and bound Ulex Europaeus lectin I. A method to establish longterm cell cultures of HIMEC will facilitate further investigation of the function of intestinal endothelial cells and their participation in physiological and pathological events in the gut.

(Gut 1995; 37: 225-234)
\end{abstract}

Keywords: intestinal mucosa, vascular endothelium, microcirculation, cell separation, cyclic AMP.

Electron Microscopy, Institute of Pathology T Hovig

Medical Department A D Kvale

\section{Institute of Surgical \\ Research}

T Scholz

Surgical

Department B

T Scholz

University of Oslo, The National Hospital, Rikshospitalet, N-0027 Oslo, Norway

Laboratory of Cellular Physiology and

Immunology, The

Rockefeller Úniversity,

New York, USA

W A Muller

Correspondence to:

Dr G Haraldsen, LIIPAT

Dr G Haraldsen, LIIPAT, Norway.

Accepted for publication 19 December 1994
Increasing evidence suggests that vascular endothelial cells are important in modulation of normal leucocyte trafficking and in mediation of inflammation. ${ }^{12}$ Regulation of haemostasis is another central role of the endothelium. ${ }^{34}$ The participation of endothelial cells in various biological phenomena in the gut, however, has been difficult to elaborate in the absence of a valid culture model. There is good reason to believe that intestinal endothelial cells behave differently from their counterparts in other vascular beds. ${ }^{56}$ Knowledge about the structure and function of human endothelial cells stems primarily from studies of large vessel endothelial cells, whereas physiological and pathological events take place mainly at the level of the microvasculature. Recent work has furthermore shown several differences between the endothelium isolated from large vessels and cultured microvascular endothelium. ${ }^{7-10}$ Immunohistochemical mapping of cellular antigen expression in situ supports this view. ${ }^{911-16}$ Functional studies based on large vessels may therefore not be valid for microvascular endothelium.

Our report describes a procedure for longterm culture of human intestinal microvascular endothelial cells (HIMEC) isolated from the normal gut by: (a) primary selection of adherent cells; (b) growth of these primary cultures to confluence; and (c) by means of paramagnetic beads coated with a monoclonal antibody (mAb) to CD31. This cell surface antigen is a $130-140 \mathrm{kD}$ single chain glycoprotein found on endothelial cells, leucocytes ( $\mathrm{T}$ cells, monocytes/macrophages, granulocytes, and $40 \%$ of bone marrow cells), and platelets, ${ }^{17}$ but not on fibroblasts (the major contaminating cell type). Immunohistochemical studies of normal intestinal biopsy specimens have reported microvascular endothelial cells to express CD31 in situ. ${ }^{18}$

\section{Methods}

\section{MATERIALS}

Chemicals, hormones, and growth factors

Dithiothreitol, $\quad N^{6}, \quad \mathrm{O}^{2}$-dibutyryladenosine cyclic monophosphate (db-cAMP), $N^{6}$-monobutyryladenosine cyclic monophosphate (mbcAMP), $n$-butyric acid, heparin, acridine orange, ethidium bromide, propidium iodide, hydrocortisone, endothelial cell growth supplement (ECGS), recombinant human epidermal growth factor (EGF), and gelatin were all purchased from Sigma Chemical Company (St Louis, MO). Recombinant human basic fibroblast growth factor (bFGF), gentamicin, and amphotericin $B$ were obtained from Gibco BRL (Paisley, Scotland), EDTA from Ferak (Berlin, Germany), HEPES buffer from Biowhittaker (Walkersville, MD), and rat tail derived type I collagen (Vitrogen) from Celtrix Laboratories (Palo Alto, CA).

\section{Culture media and serum samples}

Endothelial-SFM (growth medium and plating medium $)^{19}$ and fetal calf serum were purchased from Gibco BRL, RPMI 1640 from Biowhittaker, endothelial basal medium (a modification of MCDB 13120) from Promocell (Heidelberg, Germany), and pooled human AB serum from Sigma.

\section{Enzymes}

Collagenase A, dispase I, and DNase were obtained from Boehringer Mannheim 
Primary antibodies used for immunoselection and immunocytochemistry

\begin{tabular}{llcll}
\hline Antibody/clone & Specificity & $\begin{array}{l}\text { Working } \\
\text { concentration }\end{array}$ & Specifications & Source \\
\hline hec7 & CD31 & $0 \cdot 4 \mu \mathrm{g} / \mathrm{ml}$ & Mouse IgG2a, supernatant & (ref 18) \\
TEA 1/31 & VE-cadherin & $1: 10$ & Mouse IgG1, supernatant & E Dejana, Milan, Italy \\
von Willebrand factor & von Willebrand factor & $1: 350$ & Rabbit antiserum, IgG fraction & $\begin{array}{l}\text { Dakopatts, Glostrup, Denmark } \\
\text { PD7/26 and 2B11 }\end{array}$ \\
PG-M1 & CD45 & $1: 50$ & Mouse IgG1, supernatant & Dakopatts \\
R-505 & CD68 & $18 \mu \mathrm{g} / \mathrm{ml}$ & Mouse IgG3, supernatant & Dakopatts \\
& Cytokeratin & $1: 100$ & Rabbit antiserum & Authors' laboratory \\
\hline
\end{tabular}

(Mannheim, Germany) and trypsin/versene solution from Biowhittaker.

\section{Primary antibodies and secondary immune reagents}

The Table summarises the primary antibodies. The generation of anti-human CD31 (mAb hec7) has been described elsewhere. ${ }^{18}$ Antibody specific for VE-cadherin (mAb TEA $1 / 31)^{21}$ was a kind gift of Dr E Dejana (Milan, Italy). Rhodamine labelled swine antirabbit IgG conjugate was from Dakopatts (Glostrup, Denmark), and streptavidin-isothiocyanate fluorescein (FITC) conjugate from Boehringer Mannheim. Ulex Europaeus lectin I-FITC conjugate, a sensitive marker for human endothelium in several tissues, ${ }^{22} 23$ and biotinylated horse antimouse IgG were from Vector Laboratories (Burlingame, CA).

\section{Paramagnetic beads}

Paramagnetic monodisperse beads $(450 \mathrm{~nm})$ coated with sheep antimouse $\mathrm{IgG}$ as well as a magnetic particle concentrator were obtained from Dynal (Oslo, Norway).

\section{Cell culture equipment}

T25 culture flasks $\left(25 \mathrm{~cm}^{2}\right)$ with a $0.22 \mu \mathrm{m}$ vented cap and 96 well tissue culture trays with detachable 8 well strips were purchased from Costar (Cambridge, MA), 96 well tissue culture trays from Falcon (Becton Dickinson, Mountain View, CA), and Lab-Tek tissue culture chamber slides from Nunc (Roskilde, Denmark).

\section{TISSUE DISSOCIATION}

Segments of human small intestine were obtained from brain dead organ donors kept on assistant ventilation for organ transplantation. After the organs were retrieved, a $20 \mathrm{~cm}$ segment of the proximal jejunum was harvested. The gut segments were opened along the antimesenteric side and rinsed extensively in sterile saline. The specimens were further prepared immediately or, alternatively, could be stored in RPMI 1640 containing 5\% fetal calf serum and gentamicin/amphotericin B at $4^{\circ} \mathrm{C}$ for up to 32 hours. The tissue was next incubated in $1 \mathrm{mM}$ dithiothreitol in isotonic $\mathrm{Ca}^{++}$and $\mathrm{Mg}^{++}$-free phosphate buffered saline (PBS, pH 7.5) for 15 minutes at $20^{\circ} \mathrm{C}$ and subsequently washed in PBS. Mucus was carefully wiped away before two additional washings in PBS. Epithelial cells were removed by four subsequent incubations in $5 \mathrm{mM}$
EDTA/PBS (30 minutes, $37^{\circ} \mathrm{C}$ ) and intervening PBS rinses with mild surface scraping. The mucosa with adjoining submucosa was then carefully dissected from the external musculature, cut into small pieces, and incubated for one hour at $37^{\circ} \mathrm{C}$ in RPMI 1640 containing $1 \mathrm{mg} / \mathrm{ml}$ collagenase $\mathrm{A}, 2 \mathrm{mg} / \mathrm{ml}$ dispase, $0.04 \mathrm{mg} / \mathrm{ml} \mathrm{DNase,} 50 \mu \mathrm{g} / \mathrm{ml}$ gentamicin, $0.25 \mu \mathrm{g} / \mathrm{ml}$ amphotericin-B, and $20 \mathrm{mM}$ HEPES buffer. Cold PBS was added next and the cell suspension sequentially passed through 200, 140, and $94 \mu \mathrm{m}$ stainless steel meshes (Bellco Glass, Vineland, NJ). The final eluate consisted mainly of single cells and capillary loops with little contaminating debris. The viability ranged from $70 \%$ to $95 \%$ as judged by the acridine orange/ethidium bromide test. ${ }^{24}$ The cell suspension was finally separated on Lymphoprep density gradient to remove granulocytes and erythrocytes; remaining cells (including endothelial cells) from the interphase were washed and resuspended in RPMI containing $10 \%$ fetal calf serum and $0.5 \mathrm{mM}$ $\mathrm{db}-\mathrm{cAMP}$.

\section{PLATING PROCEDURE}

Cells were plated at a seeding density of $1 \times 10^{6}$ per $\mathrm{cm}^{2}$ into T25 culture flasks coated with monomeric non-fibrillar collagen as described by the manufacturer. After 60 minutes nonadherent cells were removed and the medium changed to growth medium containing $2.5 \%$ fetal calf serum (see later). In some experiments, cells were plated on $1 \%$ gelatin or in endothelial-SFM plating medium (containing vitronectin).

\section{ENDOTHELIAL CELL ISOLATION}

The paramagnetic bead selection was performed as previously described ${ }^{25}$ with the following modifications. The primary cell cultures were grown to subconfluence. A single cell suspension was obtained by applying trypsin $(0.5 \mathrm{mg} / \mathrm{ml}, 1: 250)$ and EDTA $(0.2$ $\mathrm{mg} / \mathrm{ml}$ ) in PBS for two to four minutes at $37^{\circ} \mathrm{C}$. Paramagnetic sheep antimouse IgG coated monodisperse beads were armed according to the manufacturer with antihuman CD31 (mAb hec7, $0 \cdot 2 \mu \mathrm{g}$ antibody/mg beads). A small fraction of cells was mixed with armed beads and briefly centrifuged $\left(400 \mathrm{~g}, 1 \mathrm{~min}, 4^{\circ} \mathrm{C}\right)$ and the percentage of rosetted cells was estimated in a haemocytometer. On the basis of this preliminary test the suspension was rosetted at a bead:target cell ratio of $5: 1$. The rosettes were extracted by a magnetic particle concentrator for two minutes after which non-rosetted cells were removed. Rosetted cells were washed six 
times, resuspended in normal growth medium, and plated into T25 culture flasks.

\section{CELL CULTURE}

Endothelial-SFM is a medium designed for the serum free culture of animal endothelial cells. ${ }^{19}$ HIMEC were grown in this medium with the addition of $2.5 \%, 1 \mu \mathrm{g} / \mathrm{ml}$ hydrocortisone, 0.5 $\mathrm{mM}$ dibutyryl cAMP, $50 \mu \mathrm{g} / \mathrm{ml}$ gentamicin, and $0.25 \mu \mathrm{g} / \mathrm{ml}$ amphotericin-B. The cells were maintained at $37^{\circ} \mathrm{C}$ in a humid $95 \%$ air:5\% $\mathrm{CO}_{2}$ atmosphere. The medium was changed twice weekly. Confluent cultures were split 1:2 or $1: 3$ by trypsin/EDTA detachment. In some experiments, endothelial cells were cultured in RPMI 1640 or endothelial basal medium with the same supplements as described.

Human foreskin derived fibroblasts (kindly provided by Dr Ken Purvis, Institute of Pathology, Rikshospitalet) were cultured in RPMI 1640 with $10 \%$ fetal calf serum.

\section{IMMUNOCYTOCHEMISTRY}

Histologically normal intestinal biopsy specimens were obtained by endoscopy from patients with non-ulcer dyspepsia. The specimens were collected in ice cold isotonic saline, snap frozen in liquid nitrogen within one hour, and stored at $-70^{\circ} \mathrm{C}$ until sectioning. Cryosections were cut at $4 \mu \mathrm{m}$, air dried, and acetone fixed $\left(10 \mathrm{~min}, 20^{\circ} \mathrm{C}\right)$ before immunostaining. HIMEC were grown to confluence in chamber slides, rinsed in PBS, and fixed in acetone $\left(10 \mathrm{~min}, 20^{\circ} \mathrm{C}\right)$.

\section{Staining protocol}

Monolayers of HIMEC as well as tissue sections were first incubated for one hour with mAbs (Table), then with a rabbit antihuman von Willebrand factor (IgG fraction, 1.5 hours) combined with biotinylated horse antimouse IgG (1:20, 1.5 hours), and finally with a rhodamine labelled swine antirabbit IgG (1:80, $30 \mathrm{~min}$ ) in combination with streptavidin-FITC conjugate $(1: 50,30 \mathrm{~min})$. Other preparations were incubated for one hour with Ulex Europaeus lectin I-FITC conjugate ( $2 \mu \mathrm{g} / \mathrm{ml}$ ), followed by rabbit antihuman von Willebrand factor ( 1 hour), and then by rhodamine labelled swine antirabbit IgG (30 min). Controls were: (a) cells or tissue slides incubated with secondary reagents only; (b) irrelevant subclass matched primary antibodies; and (c) cultured human foreskin derived fibroblasts. The sections were examined in a Leitz DM RX/E fluorescence microscope equipped with a DM RD photosystem (Leica, Wetzlar, Germany). Results were recorded on Ektachrome professional 800/1600 ISO daylight film developed at 800 ISO.

ELECTRON MICROSCOPY

Surface attached confluent monolayers were fixed with $2 \%$ glutaraldehyde in calcium free cacodylate buffer $(0 \cdot 1 \mathrm{M}, 30 \mathrm{~min}, \mathrm{pH} 7 \cdot 2)$ followed by osmium tetroxide $(40 \mathrm{mM})$ in cacodylate buffer with calcium ( $25 \mathrm{mM}, 20$ $\mathrm{min}$ ), and dehydration in graded alcohols. Cells were then scraped into a 1:1 mixture of Epon 812 (Fluka Chemie, Buchs, Switzerland) and propylen oxide. The pellet obtained by centrifugation (3000 $\mathrm{g}, 8 \mathrm{~min}$ ) was finally embedded in Epon 812. Sections were cut at $60 \mathrm{~nm}$ with a Reichert-Jung Ultracut E ultramicrotome (Vienna, Austria) and mounted on copper grids. The sections were stained with uranyl acetate and lead citrate and examined with a Jeol $100 \mathrm{~B}$ electron microscope (Jeol, Tokyo, Japan).

\section{FLOW CYTOMETRY}

Single cell suspensions of HIMEC and cultured human foreskin fibroblasts, obtained after trypsinisation, were centrifuged $(400 \mathrm{~g}, 5 \mathrm{~min})$ and resuspended in PBS containing $1.0 \%$ fetal calf serum, $0 \cdot 1 \% \mathrm{NaN}_{3}$, and $2.0 \mathrm{mM}$ EDTA. Cells $\left(5 \times 10^{4}\right)$ were incubated in microtitreplates at $4 \cdot \mathrm{C}$ under gentle stirring with Ulex Europaeus lectin I-FITC conjugate $(2 \mu \mathrm{g} / \mathrm{ml}$, $20 \mathrm{~min}$ ), then washed by centrifugation twice, and finally resuspended in $200 \mu \mathrm{l}$ medium containing propidium iodide $(2.5 \mu \mathrm{g} / \mathrm{ml})$. Cultured human foreskin fibroblasts served as control. Cell samples were analysed on a fluorescence activated cell scanner (FACScan, Becton Dickinson) and $6 \times 10^{3}$ gated living cells were acquired in list mode for each sample.

\section{DETERMINATION OF CELL PROLIFERATION}

Endothelial cell proliferation was determined by a modification of the procedure described by Gillies et al. ${ }^{2627}$ Briefly, formalin fixed adherent cells were air dried and stained with $0.1 \%$ crystal violet in PBS for five minutes followed by repeated rinses in water. The nuclear dye was eluted with $33 \%$ acetic acid and optical density was recorded at $570 \mathrm{~nm}$ in a Titertek Multiscan microplate photometer (Flow, Helsinki, Finland).

For determination of growth rates, cells were cultured in 96 well trays with separately detachable strips, which were fixed on various days as shown in the Figures, stored at $4^{\circ} \mathrm{C}$ until termination of the experiment, and then stained by crystal violet. Media were changed daily unless otherwise indicated. Medians from triplicate wells were plotted. The results shown are in each case representative for three experiments.

\section{STATISTICS}

The correlation between cell number and optical density was estimated by means of Pearson's correlation coefficient.

\section{Results}

ESTABLISHMENT OF HIMEC CULTURES

\section{Primary plating}

Plating of the cell suspension obtained after tissue dissociation resulted in a mixed 

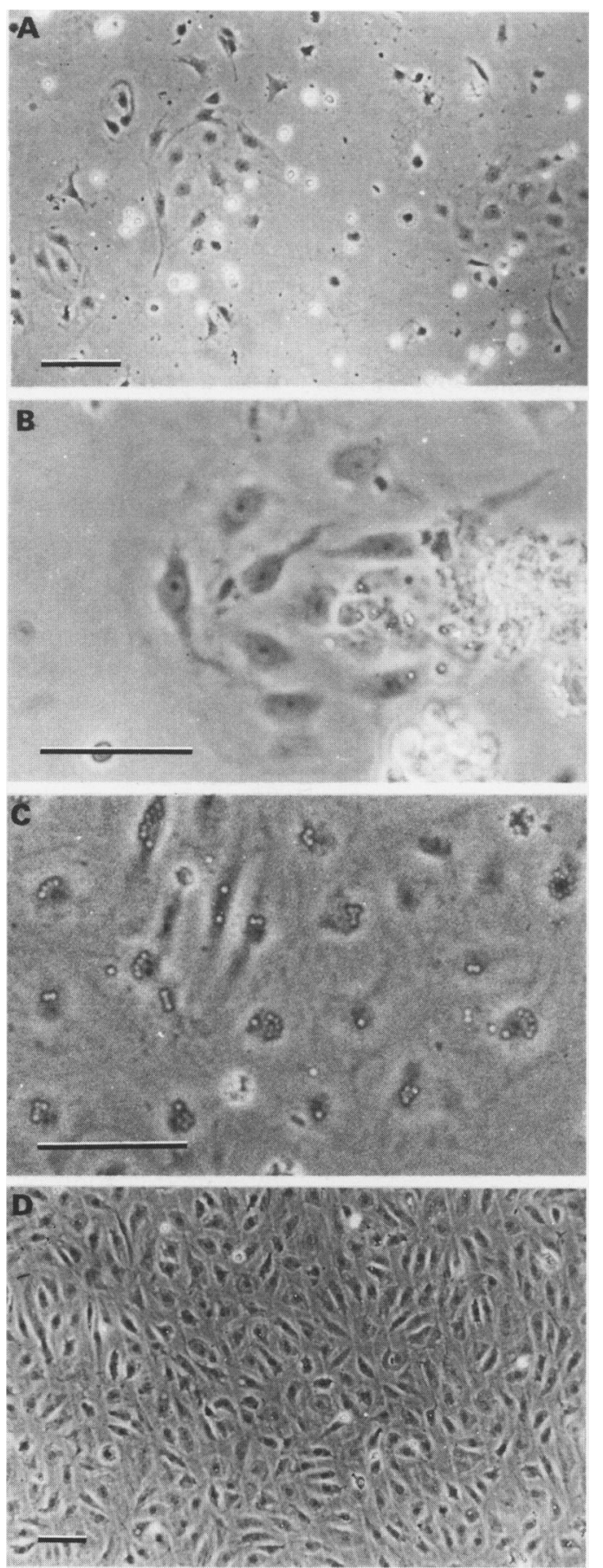

Figure 1: HIMEC cultures. (A) Mixed primary cell culture obtained from human gut wall two days after plating. Endothelial cell colonies containing 2-15 cells are surrounded by fibroblastoid and semi-adherent cells. Phase contrast micrograph. (B) One endothelial cell colony at higher magnification. (C) Cells in first passage selected by paramagnetic beads coated with anti-CD31 (one day after plating). (D) Confluent monolayer of second passage cells, nine days after plating. Scale bars $=100 \mu \mathrm{m}$.

population of adherent cells. On day one or two, small endothelial cell colonies consisting of two to 15 cells were detected, being surrounded by fibroblastoid cells and semiadherent cells (Fig 1A, B). Prolonged plating time resulted in more fibroblastoid cells without increasing the number of endothelial cell colonies. The intestinal endothelial cells were of epitheloid shape with a light nucleus containing one or two nucleoli as judged by phase contrast microscopy. The immediate perinuclear cytoplasm was dark and surrounded by a bright halo. The limits of the cytoplasm were difficult to visualise by phase contrast microscopy.

The highest number of colonies was obtained on collagen coated surfaces. Endothelial cells, however, could also adhere and proliferate on gelatin or vitronectin but not on uncoated plastic. Moreover, serum free conditions could maintain these primary cultures for only a few days (data not shown). At least $2.5 \%$ fetal calf serum was required in primary cultures; higher concentrations resulted in increased numbers of endothelial cells but fibroblast growth was also stimulated (data not shown).

\section{Isolation of endothelial cells}

On day five to seven, when cultures were subconfluent, paramagnetic bead separation of $\mathrm{CD} 31^{+}$cells was carried out and usually resulted in $10-30 \%$ rosettes that were replated (Fig 1C). Most of the beads detached from the cells during the following few days and were not detectable in the next passage. The secondary cultures reached confluence after seven to nine days (Fig 1D). Contaminating fibroblastoid cells (as judged by phase contrast microscopy) were rarely seen and, when present, were easily eliminated by an additional bead separation.

\section{GROWTH CONDITIONS FOR SECONDARY HIMEC} CULTURES

Quantification of endothelial cell growth was performed using crystal violet staining, which measures reliably even small cell numbers. ${ }^{26}$ The relation between cell numbers and dye intensity was examined by plating serially diluted cells in triplicate wells ranging from 0.5 to $32 \times 10^{3}$ cells per well. After six hours the cells were fixed and stained. Correlation coefficients were greater than 0.99 and there was a linear relation between cell number and optical density (data not shown).

\section{Medium}

The proliferation rate of HIMEC in RPMI 1640 , endothelial basal medium, or endothelialSFM was compared at $2 \cdot 5 \%, 10 \%$, and $20 \%$ fetal calf serum. SFM medium proved slightly better than endothelial basal medium and RPMI (data not shown). In RPMI the cells soon acquired an irregular shape and resembled senescent cultures even in the presence of $20 \%$ fetal calf serum. Endothelial-SFM was therefore chosen as standard medium.

\section{Serum type and concentration}

Figure 2 shows the influence of fetal calf serum on proliferation rate of purified endothelial cells. Without serum there was a slight increase in cell number during the first seven days, after which a numeric decline and a general deterioration of the cell culture were seen. The growth rate increased with higher serum concentrations, peaking at $10 \%$ serum. Pooled human $A B$ serum at $2 \cdot 5-20 \%$ was also tested, 


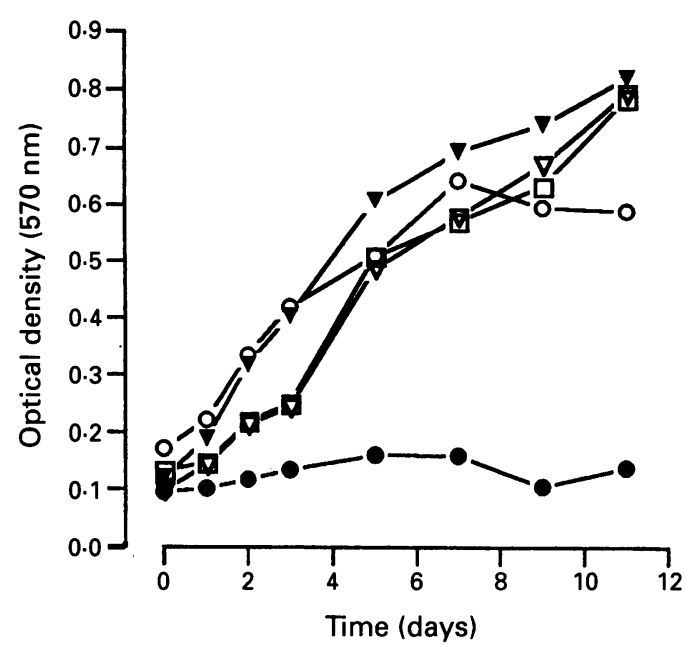

Figure 2: Effect of fetal calf serum on growth rate of HIMEC cultures. Plating was performed in $100 \mu l$ standard medium ( 3000 cells per well) with $0 \%(0)$, $1.0 \%(\square), 2 \cdot 5 \%(\nabla)$, and $50 \%$ (O) serum added as $100 \mu l$ solutions at twice the final concentration in 96 well trays. Media were changed daily. Cells were fixed on various days as shown and stained with crystal violet to record proliferation (results measured at $570 \mathrm{~nm}$ ).

Representative result from one of three experiments

(medians from triplicate wells plotted). Ranges were within $15 \%$ of the median.

but appreciable differences from fetal calf serum were not seen (data not shown).

\section{cAMP analogues}

Endothelial cells were exposed for 72 hours to varying concentrations $(30 \mu \mathrm{M}-10 \mathrm{mM})$ of $n$-butyric acid and the cyclic AMP analogues $N^{6}, \mathrm{O}^{2}$-dibutyryl cAMP (db-cAMP) and $N^{6}$-monobutyryl cAMP (mb-cAMP) (Fig 3A). Increasing concentrations of db-cAMP and mb-cAMP resulted in a similarly increased number of cells, whereas $n$-butyric acid had no apparent effect. In the course of 10 days, more than $1 \mathrm{mM}$ db-cAMP was required for endothelial cells to reach confluence (Fig 3B).

\section{ECGS}

Endothelial cell growth supplement (ECGS), which is a crude preparation of acidic fibroblast growth factor (aFGF), was tested at $1-300 \mu \mathrm{g} / \mathrm{ml}$ in growth medium containing 18 IU heparin (Fig 4). Without addition of db-cAMP, cell growth was moderately stimulated by increasing concentrations of ECGS. In the presence of only $0.5 \mathrm{mM}$ db-cAMP, however, the cells grew even faster than with ECGS alone at $300 \mu \mathrm{g} / \mathrm{ml}$, showing only a minimal effect of ECGS on HIMEC growth.

\section{$b F G F$}

Basic fibroblast growth factor (bFGF) was tested at $3 \mathrm{pg}-10 \mathrm{ng} / \mathrm{ml}$ in standard growth medium. A minimal stimulatory effect on growth was seen after 72 hours (data not shown), but after seven days the number of endothelial cells grown in the presence of $1 \mathrm{ng} / \mathrm{ml} \mathrm{bFGF}$ was twofold higher than controls (Fig 5). Wells were examined by microscopy before elution of crystal violet and were free from contaminating fibroblasts.
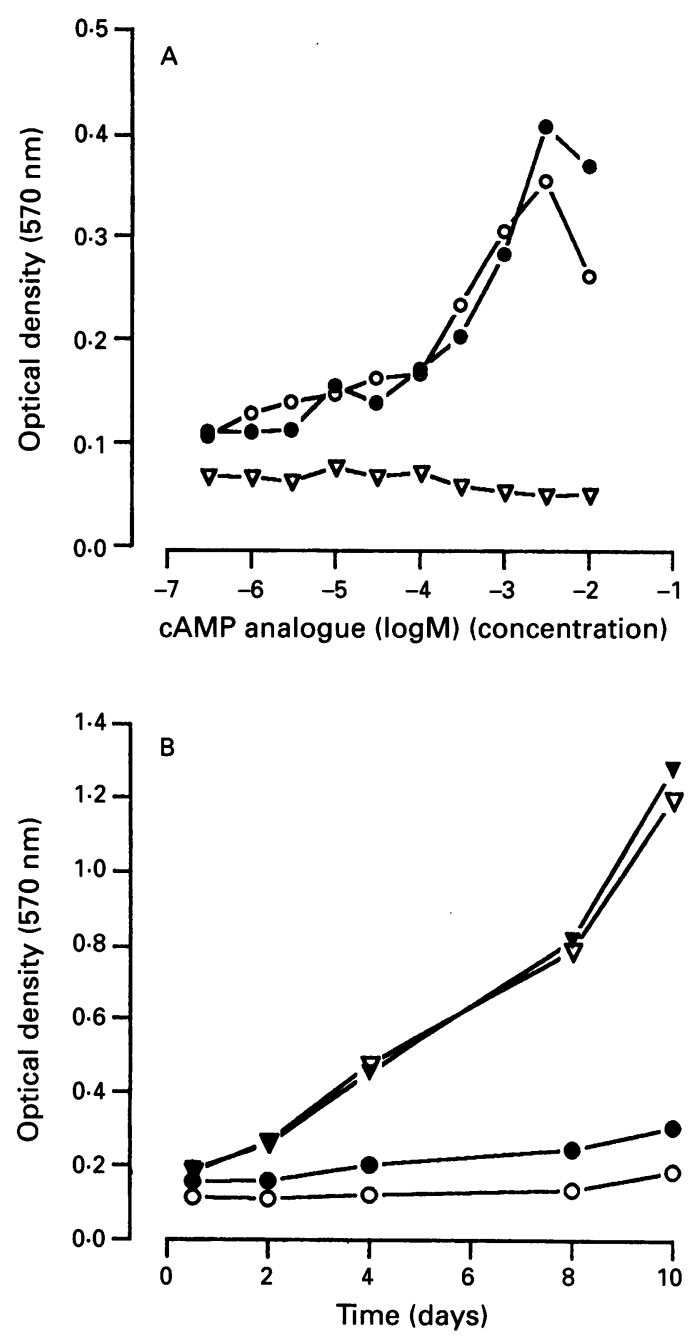

Figure 3: Effect of cAMP analogues on cell proliferation of HIMEC cultures. (A) Dose response to $d b-c A M P(\mathrm{O})$, $m b-c A M P(O)$, and $\mathrm{n}$-butyrate $(\nabla)$. Cells (3000 per well) were plated in standard medium $(2 \cdot 5 \%$ fetal calf serum) and fixed after 72 hours. (B) Effect of db-cAMP on growth rate. Cells (3000 per well) were plated and incubated without (O), or with $0.1 \mathrm{mM}(\mathrm{O})$, $1 \mathrm{mM}(\nabla)$, and $10 \mathrm{mM}(\nabla)$ of $d b-c A M P$. Representative result from one of three experiments (medians from triplicate wells plotted). Ranges were within $15 \%$ of the median.

\section{$E G F$}

Epidermal growth factor (EGF) was tested at $1-10 \mathrm{ng} / \mathrm{ml}$ without any apparent effect on cell proliferation even after nine days. By contrast, this EGF preparation induced moderate proliferation of human umbilical vein endothelial cells (HUVEC) under identical conditions (data not shown).

\section{Hydrocortisone}

Hydrocortisone was tested at $0.01-1 \mu \mathrm{g} / \mathrm{ml}$ and induced about twofold increase in cell counts at $1 \mu \mathrm{g} / \mathrm{ml}$ after five days (Fig 6).

\section{CELL IDENTIFICATION}

\section{Immunohistochemistry}

Cryosections of normal intestinal biopsy specimens immunostained for CD31 showed strongly positive vessels that always coexpressed von Willebrand factor (Fig 7A and B). Some interstitial stormal cells were weakly 


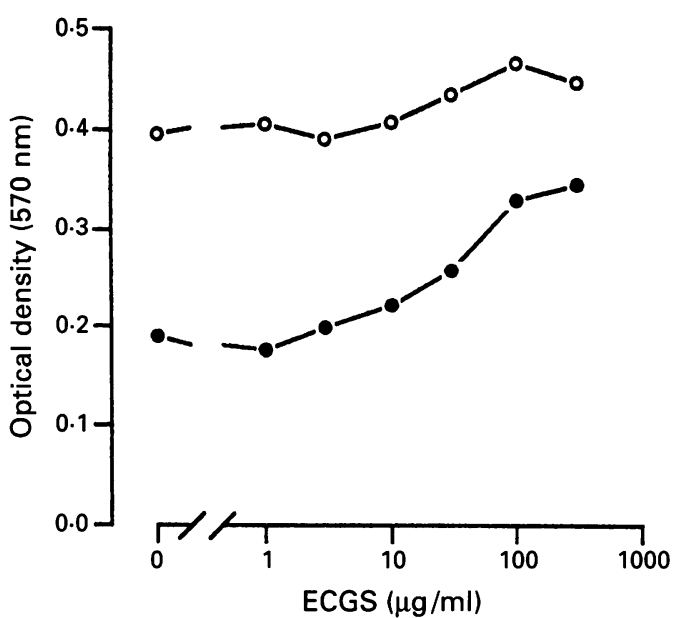

Figure 4: Effect of ECGS on cell proliferation of HIMEC cultures. Cells (3000 per well) were plated in 96 well tissue culture plates in standard medium (2.5\% fetal calf serum) containing 18 IU heparin and various concentrations of ECGS alone (O) or in combination with $0.5 \mathrm{mM}$ $d b-c A M P(O)$ for 72 hours. Representative result from one of three experiments (medians from triplicate wells plotted). Ranges were within $15 \%$ of the median.

positive for CD31 as well. Immunostaining was also performed with mAb TEA $1 / 31$ specific for VE-cadherin; this marker is selectively expressed by endothelial cells in several human tissues. ${ }^{28}$ Costaining for von Willebrand factor showed that mAb TEA reacted exclusively with vascular structures in the human intestine (data not shown). Ulex Europaeus lectin I, a sensitive marker for endothelial cells that recognises $\alpha$-L-fucose residues on glycoproteins and glycolipids, ${ }^{22}$ stained endothelial cells in situ but also the brush border of the intestinal epithelium (data not shown).

Confluent monolayers of HIMEC expressed von Willebrand factor in a granular pattern throughout the cytoplasm (Fig 8A); most cells were positive up to the fifth passage, after which there was a slow decline in the proportion of von Willebrand factor positive cells. However, cells continued to express VEcadherin up to the eight passage. The staining

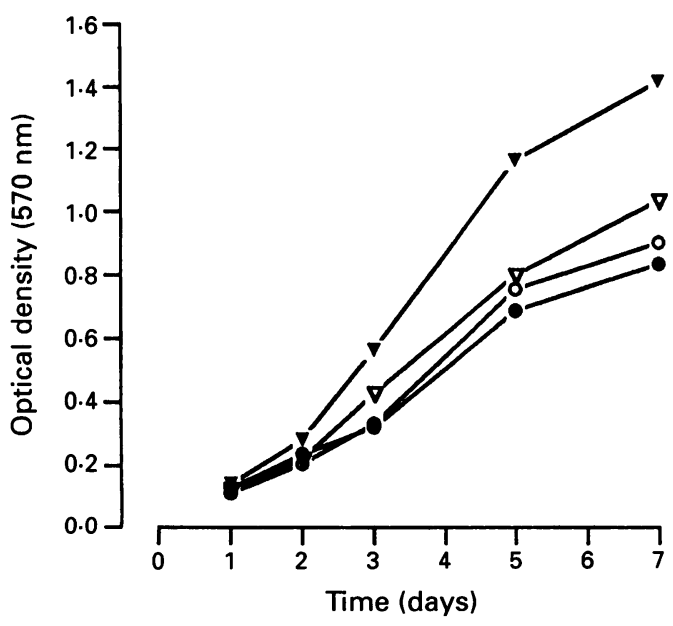

Figure 5: Effect of bFGF on growth rate of HIMEC cultures. Cells (3000 per well) were plated in standard medium ( $2.5 \%$ fetal calf serum) containing $0.5 \mathrm{mM}$ db-cAMP and incubated without (O) or with $0.01 \mathrm{ng} / \mathrm{ml}$ (O), $0.1 \mathrm{ng} / \mathrm{ml}(\nabla)$, and $1.0 \mathrm{ng} / \mathrm{ml}(\nabla)$ of $b F G F$. Representative result from one of three experiments (medians from triplicate wells plotted). Ranges were within $15 \%$ of the median.
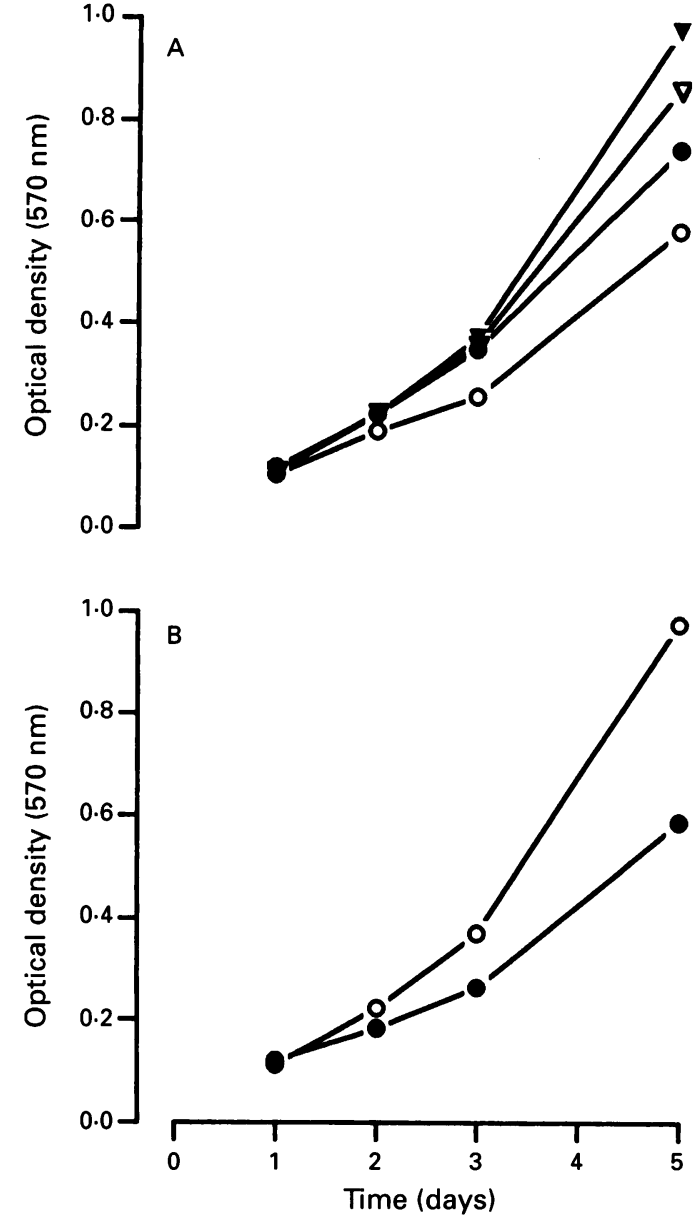

Figure 6: Effect of hydrocortisone on growth rate of HIMEC cultures. (A) Cells (3000 per well) were plated in standard medium ( $2 \cdot 5 \%$ fetal calf serum) and incubated without (O) or with $0.01 \mu \mathrm{g} / \mathrm{ml}(\mathrm{O}), 0.1 \mu \mathrm{g} / \mathrm{ml}(\nabla)$, and $1.0 \mu \mathrm{g} / \mathrm{ml}$ ( ( ) hydrocortisone. (B) Ethanol, the solvent for hydrocortisone (final concentration: $0 \cdot 1 \%$ ) was included in parallel control wells in which cells were cultured with ethanol alone (O) or with $1 \mu \mathrm{g} / \mathrm{ml}$ hydrocortisone dissolved in the same amount of ethanol (O).

Representative result from one of three experiments (medians from triplicate wells plotted). Ranges were within $15 \%$ of the median.

was restricted to the region of intercellular contact with some additional weak reactivity surrounding the nucleus (Fig 8B). Staining for CD31 on cultured HIMEC showed a similar reactivity at the intercellular junctions, particularly when the cells reached confluence (data not shown); a staining pattern identical to that described for HUVEC. ${ }^{18} \mathrm{CD} 31$ reactivity was maintained on most cells up to the eight passage. HIMEC furthermore bound Ulex Europaeus lectin I (see later). Staining of established monolayers with anti-CD45 (leucocyte common antigen), anti-CD68 (macrophage restricted form), and anticytokeratin showed no contaminating cells (data not shown).

\section{Electron microscopy}

The Weibel-Palade organelle, a unique ultrastructural endothelial cell marker, was present in moderate numbers in cultured HIMEC (Fig 9A and B). The cells furthermore contained micropinocytotic vesicles (Fig 9A (insert)). Filaments were seen in scarce amounts. 

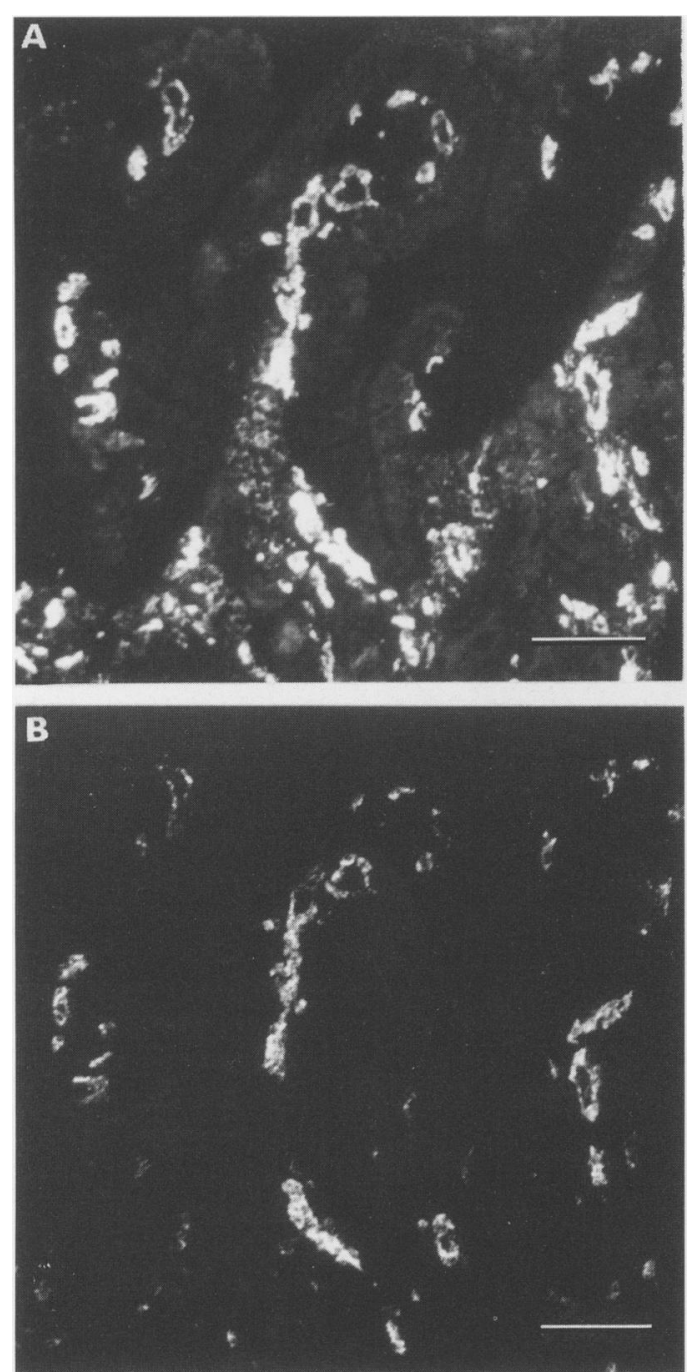

Figure 7: In situ coexpression of $C D 31(A)$ and von Willebrand factor $(B)$ in the same field of normal himan intestinal lamina propria. Two colour immunofluorescence staining of microvascular endothelial cells in acetone fixed cryosection. Scale bars $=100 \mu \mathrm{m}$.

\section{Flow cytometry}

Cultured HIMEC were assessed for purity by means of Ulex Europaeus lectin I applied in flow cytometry; uniform reactivity was seen in the cell population (Fig 10). Cultured foreskin derived fibroblasts served as a negative control.

\section{REPRODUCIBILITY}

Endothelial cell isolation was performed with 47 intestinal samples. From every sample $250 \times 10^{6}$ cells were plated in $10 \mathrm{~T} 25$ bottles. It was then usually possible to harvest one to two $\times 10^{6}$ rosetted cells that underwent $10-15$ population doublings. Eight samples were discarded on the first day after isolation because of fungal infection, and two samples became infected by bacteria. All remaining cultures were brought through at least passage two; 15 cultures being cultured to passage seven or higher.

\section{Discussion}

This is to the best of our knowledge the first description of isolation and longterm culture of HIMEC. In the lamina propria and
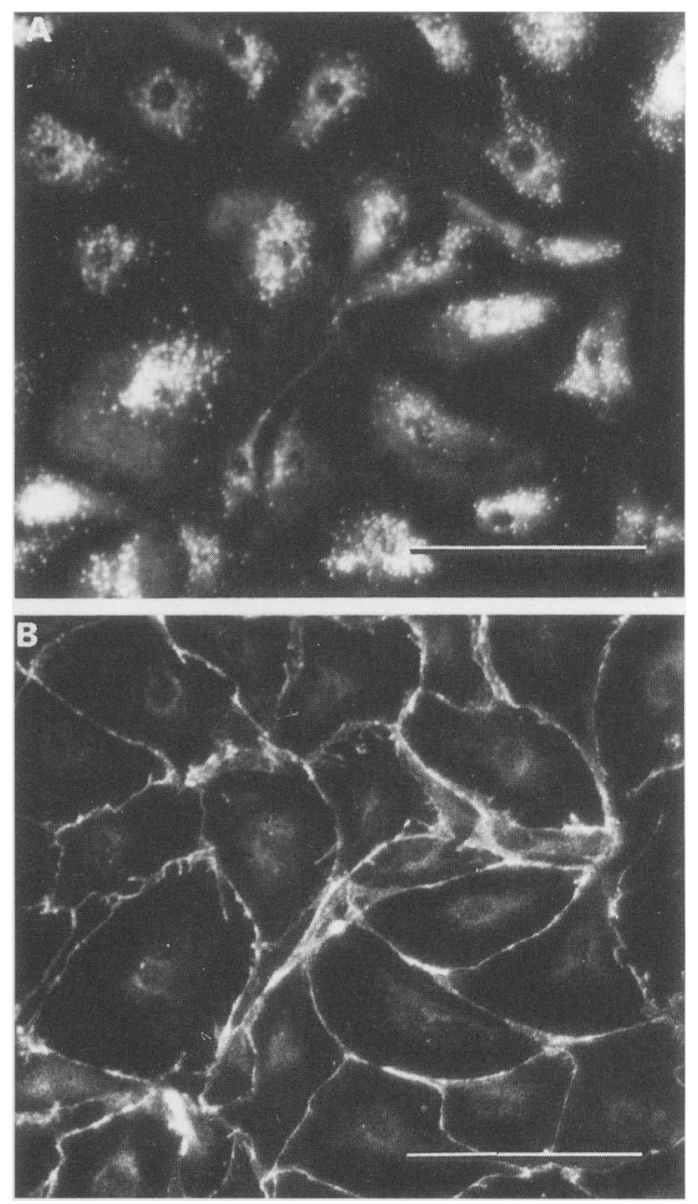

Figure 8: Coexpression of von Willebrand factor $(A)$ and $V E$-cadherin (B) in cultured HIMEC. Two colour immunofluorescence staining of acetone fixed confluent monolayer. Scale bars $=100 \mu \mathrm{m}$.

submucosa such cells probably play a decisive part for the normal homing of leucocytes as well as for the extravasation that takes place in intestinal inflammatory lesions. According to current knowledge of lymphocytes destined for the intestine, naive cells home mainly to gut associated lymphoid tissues by crossing high endothelial venules and the $T$ cell areas, whereas memory cells migrate predominantly across flat endothelial surfaces in the mucosal lamina propria. ${ }^{29}$ Some of the endothelial cell molecules involved in the homing of lymphocytes to gut associated lymphoid tissues are well characterised, at least in non-human species, ${ }^{30}$ but adhesion molecules that regulate selectively normal lymphocyte extravasation at tissue sites where high endothelial venules are lacking have not been identified. ${ }^{31}$ In the pathogenesis of inflammatory bowel disease both immunological hypersensitivity ${ }^{32}$ and vascular lesions ${ }^{33} 34$ have been implicated. Furthermore, increased perivascular endothelin-1 immunoreactivity was recently described in both Crohn's disease and ulcerative colitis, suggesting a link between the two pathogenetic hypotheses. ${ }^{35}$ Thus microvascular gut endothelial cells may play a central part both in coagulation, in normal and inflammatory adherence and transmigration of leucocytes, as well as in the production of endothelin-1.

The role endothelial cells play in these interactions in the human gut has hitherto 

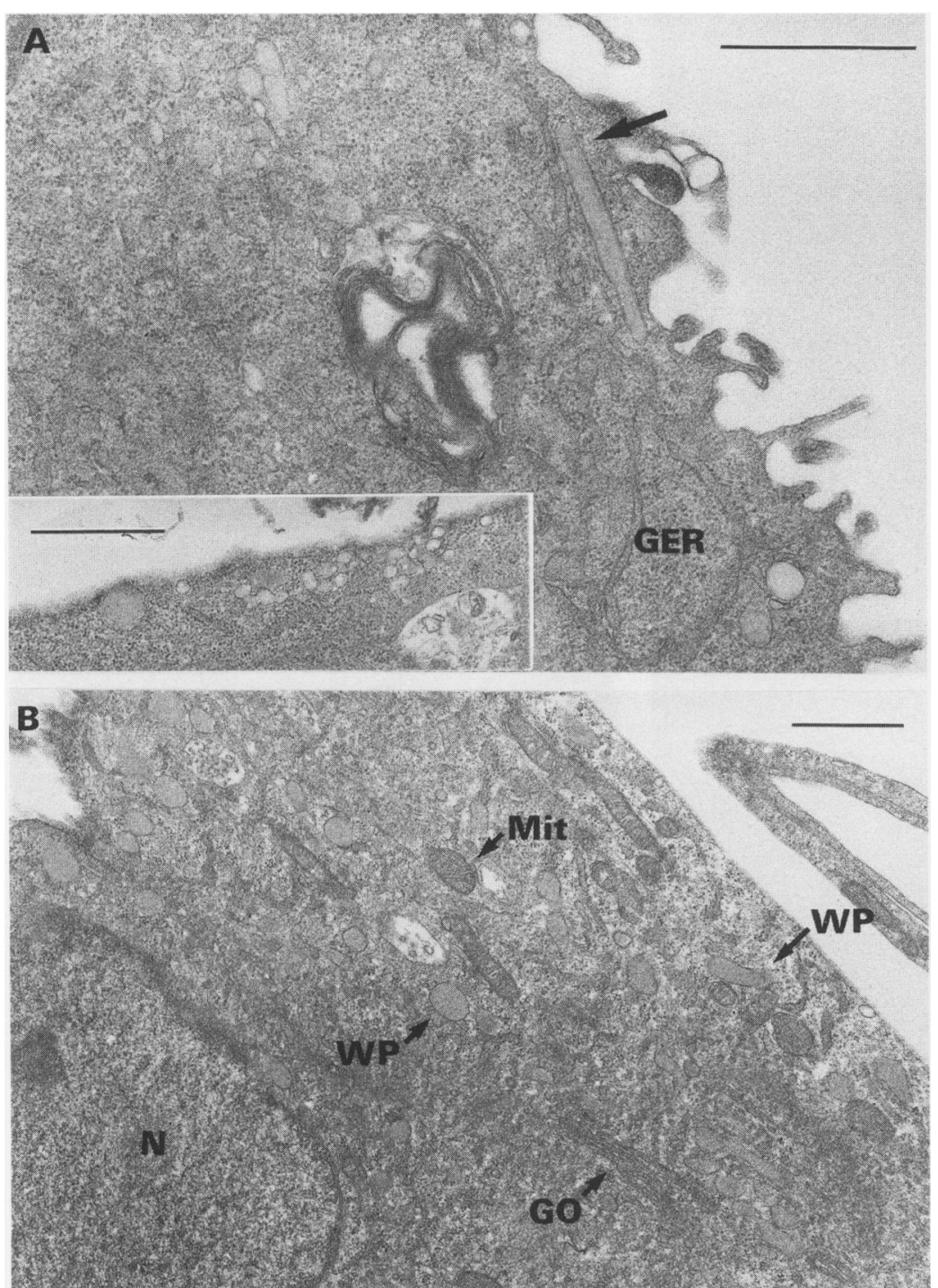

Figure 9: Electron micrographs of cultured HIMEC. (A) Note the profile of one WeibelPalade body cut longitudinally (arrow). GER=granular endoplasmatic reticulum. Insert: micropinocytotic vesicles. (B) Several Weibel-Palade bodies cut perpendicular to the long axis. $W P=$ Weibel-Palade body, $G O=$ Golgi complex, Mit $=$ mitochondrion, $N=$ nucleus . Scale bars $=1 \mu \mathrm{m}$. been difficult to unravel because of the lack of a valid culture model. Most of what is known about the structure and function of human endothelial cells stems from studies of HUVEC. Data from large vessel endothelial cell cultures must be interpreted with caution, however, because functionally important molecules might be differentially expressed and regulated in microvascular endothelial cells. ${ }^{5899}$ Furthermore, most physiological and pathological events take place at the level of the microvasculature. Immunohistochemical analyses of tissue antigens have shown that small vessel endothelial cells are phenotypically different from their large vessel counterparts ${ }^{911-1636}$ and some of these molecules are not found on HUVEC. ${ }^{15} 36$ Progress in the isolation and culture of microvascular endothelial cells ${ }^{73} 38$ has confirmed the phenotypic heterogeneity of endothelial cells and has also shown differences with regard to their in vitro growth requirements, ${ }^{7}$ prostaglandin production, ${ }^{8}$ ability to form tubes in vitro, ${ }^{39}$ immunological phenotypes, ${ }^{9}$ and the regulation of cell adhesion molecules. ${ }^{10} 40$

Endothelial cell cultures were in our study obtained from jejunal segments of organ donors but similar results could be achieved with colonic and rectal resection specimens (unpublished findings). A pure endothelial cell population required the following steps: (a) removal of slow adhering cells after 60 minutes of plating; (b) comparatively low serum concentrations to inhibit the growth of fibroblastoid cells; and (c) endothelial cell selection by means of the CD31 antigen, which in the lamina propria was found to be most strongly expressed on endothelial cells and apparently absent from fibroblasts (the major contaminating cell in the primary cultures). Other cellular elements showed low in situ reactivity for CD31, and these undefined putative contaminators were presumably either without adherent or proliferative potential under the present culture conditions. CD31 was preferred as selection antigen because it is one of the few endothelial cell surface molecules that shows trypsin resistance and persists in culture over several passages. We have previously bead selected endothelial cells by means of $\mathrm{CD} 34,{ }^{41}$ but this antigen is rapidly lost during primary culture. The same applies to the mAb defined PAL-E antigen ${ }^{12}$ (our unpublished findings). The mAb EN4 has recently been shown to be CD31specific. $^{42}$

Contamination of the cultures by mesothelial cells ${ }^{43}$ was ruled out as follows: (a) the mucosa and submucosa were carefully dissected away from the external musculature before tissue digestion; (b) the cultured cells showed the characteristic granular expression of von Willebrand factor as previously described for cultured endothelial cells from several tissue sites ${ }^{74-46}$ as well as in tissue sections from the intestine (our unpublished finding); and (c) both the cultured monolayers and the intestinal microvascular endothelial cells studied in situ reacted with Ulex 
Europaeus lectin I, contrasting mesothelial cells that are negative for this marker as well as for von Willebrand factor. ${ }^{43} 47$

Contamination of the cultures by other CD31 positive cells was excluded by lack of staining for the leucocyte common antigen CD $45^{48}$ as well as the macrophage restricted form of CD68, ${ }^{49}$ whereas contamination of Ulex Europaeus lectin I binding epithelial cells was excluded by lack of staining for cytokeratin.

The endothelial cells isolated from the human intestine were cultured in a growth medium designed for serum free culture of animal endothelial cells. ${ }^{19}$ According to the manufacturer, endothelial-SFM is also useful for the culture of HUVEC after supplementation with ECGS, EGF, and hydrocortisone. These growth factors, however, as well as db-cAMP at maximum values, neither maintained primary cultures, nor induced proliferation of HIMEC in secondary cultures. Proliferation was only seen after addition of serum, reflecting the need for a hitherto unidentified growth factor.

Agents that increase cellular cAMP, or analogues of cAMP, are potent growth stimulators in human dermal microvascular endothelial cells. ${ }^{45} 50$ This information prompted us to investigate the effect of cAMP analogues on the growth rate of HIMEC. It is believed that db-cAMP dissociates intracellularly into mb-cAMP and $n$-butyric acid; both these cAMP analogues induced dose dependent cell proliferation. In agreement with Davison et al,,$^{50}$ we furthermore found that HUVEC proliferation was not influenced by exogenous cAMP (our unpublished findings). Interestingly, exogenous cAMP almost abolished the growth promoting effect of ECGS with heparin on HIMEC. ECGS is a widely used crude preparation of aFGF, a mitogen for HUVEC whose potency is greatly enhanced by the presence of heparin. ${ }^{51}$ Our data might reflect a role for cAMP as a second messenger in the proliferative effect of aFGF on intestinal microvascular endothelial cells but could also suggest that stimulation by exogenous cAMP induces a maximum growth rate in these cells.

The availability of a reproducible and comparatively simple method to establish normal HIMEC longterm cultures should permit further studies on the function of intestinal endothelial cells and their putative role in physiological and pathological events in the human gut. It has become increasingly apparent that these cells play a central part both in the normal mucosal immune system as well as in local inflammatory processes, but the detailed mechanisms remain elusive.

We thank Dr Elisabetta Dejana for the TEA 1/31 antibody, Dr Gustav Gaudernack for helpful discussions, and Dr Inger Nina Gustav Gaudernack for helpful discussions, and Dr Inger Nina Farstad for the FACS analyses, Ms Liv Mangschau and Ms Bjorg Badaro for expert cell culture, Ms Inger Johanne Ryen for excellent multicolour immunohistochemistry, and Ms Onelma Blomhoff for her technical microscopical specimens.

This study was supported by the Norwegian Cancer Society, the Norwegian Research Council, the Medinnova Governmental Research Organization, the Research Fund for Asthma and Allergy, and the Red Cross Research Fund for Children with Asthma and Allergy.
1 McEver R. Leukocyte-endothelial cell interactions. Curr Opin Cell Biol 1992; 4: 840-9.

2 Pardi R, Inverardi L, Bender JR. Regulatory mechanisms in leucocyte adhesion: flexible receptors for sophisticated travellers. Immunol Today 1992; 13: 224-30.

3 Naworth B, Kisiel W, Stern D. The role of endothelium in the homeostatic balance of haemostasis. Clin Hematol 1985; 14: 531.

4 Vane JR, Änggård EE, Botting RM. Regulatory functions of the vascular endothelium. N Engl f Med 1990; 323: 27-36.

5 Koizumi M, King N, Lobb R, Benjamin C, Podolsky DK. Expression of vascular adhesion molecules in inflammatory bowel disease. Gastroenterology 1992; 103: 840-7.

6 Haraldsen G, Rugtveit J, Jahnsen J, Scott H, Brandtzaeg P. Expression of endothelial adhesion molecules in cultured ntestinal biopsy specimens. EMRC Clinical Network for Gastroenterological Immunology. Oslo: May 21-22, 1993

7 Folkman J, Haudenschild CC, Zetter BR. Long-term culture of capillary endothelial cells. Proc Natl Acad Sci USA 1979; 76: 5217-21.

8 Charo IF, Shak S, Karasek MA, Davison P, Goldstein I. Prostaglandin $\mathrm{I}_{2}$ is not a major metabolite of arachidonic acid in cultured endothelial cells from human foreskin microvessels. F Clin Invest 1986; 74: 914-9.

9 Swerlick RA, Lee KH, Wick TM, Lawley TJ. Human dermal microvascular endothelial but not human umbidical vein endothelial cells express CD 36 in vivo and in vitro 7 Immunol 1992; 148: 78-83.

10 Swerlick RA, Lee KH, Lawley TJ. Regulation of vascular cell adhesion molecule-1 on human dermal microvascular endothelial cells. F Immunol 1992; 149: 698-705.

11 Cui YC, Tai P-C, Gatter KC, Mason MY, Spry CJF. A vascular endothelial cell antigen with restricted distribution in human foetal, adult and malignant tissues. Immunology 1983; 49: 183-9.

12 Schlingemann RO, Dingjan GM, Emeis JJ, Blok J, Warnaar SO, Ruiter DJ. Monoclonal antibody PAL-E specific for endothelium. Lab Invest 1985; 52: 71-6.

13 Holden CA, Spaul J, Williams R, Spry CJF, Jones RR, Wilson Jones $\mathrm{E}$. The detection of endothelial cell antigens in cutaneous tissue using methacarn and periodate lysine paraformaldehyde fixation. F Immunol Meth 1986; 91: 45-52.

14 Fujimoto $T$, Singer SJ. Immunocytochemical studies of endothelial cells in vivo. II. Chicken aortic and capillary endothelial cells exhibit different cell surface distributions of the integrin surface. $\mathcal{F}$ Histochem Cytochem 1988; 36: 1309-17.

15 Salmi M, Jalkanen S. A 90-kilodalton endothelial cell molecule mediating lymphocyte binding in humans. Science 1992; 257: 1407-9.

16 Salmi $M$, Kalimo K, Jalkanen S. Induction and function of vascular adhesion protein-1 at sites of inflammation. f Exp Med 1993; 178: 2255-60.

17 Hogg N, Horton M. Myeloid antigens: new and previously defined clusters. In: McMichael AJ, Beverley PCL, Cobbold S, eds. Leucocyte typing III. White cell differentiation antigens. Oxford: Oxford University Press, 1987: 589-90.

8 Muller WA, Ratti CM, McDonnell SL, Cohn ZA. A human endothelial cell-restricted, externally disposed plasmalemmal protein enriched in intercellular junctions. f Exp Med 1989; 170: 399-414.

9 Gorfien SF, Judd DA, Spector AA, Weiss SA. EndothelialSFM: a new serum-free medium for vascular endothelial cells. Focus 1992; 14: 14-6.

20 Knedler A, Ham RG. Optimized medium for clonal growth of human microvascular endothelial cells with minimal serum. In Vitro Cell Dev Biol 1987; 23: 481-91.

21 Leach L, Clark P, Lampugnani MG, Arroyo AG, Dejana E, Firth JA. Immunoelectron characterisation of the interendothelial junctions of human term placenta. $\mathcal{F}$ Cell $S c i$ 1993; 104: 1073-81.

22 Holthöfer H, Virtanen I, Kariniemi A-L, Hormia M, Linder E, Miettinen A. Ulex europaeus I lectin as a marker for vascular endothelium in human tissues. Lab Invest 1982; 47: 60 .

23 Ordonez NG, Batsakis JG. Comparison of Ulex europaeus I lectin and factor VIII-related antigen in vascular lesions. lectin and factor Virl-related antigen

24 Parks DR, Bryan VM, Oi VT, Herzenberg LA. Antigen specific identification and cloning of hybridomas with a fluorescence activated cell sorter. Proc Natl Acad Sci USA 1979; 76: 1962

25 Kvale D, Bartek J, Sollid LM, Brandtzaeg P. Rapid selection of cultured cells with increased expression of a membrane marker (secretory component). Int $\mathcal{F}$ Cancer 1988; 42: $638-41$.

26 Gillies RJ, Didier N, Denton M. Determination of cell number in monolayer cultures. Analyt Biochem 1986; 159: 109-13.

27 Kueng W, Silber E, Eppenberger U. Quantification of cells cultured on 96-well plates. Analyt Biochem 1989; 182: 16-9.

28 Lampugnani MG, Resnati M, Raiteri M, Pigott R, Pisacane A, Houen G, et al. A novel endothelial-specific membrane protein is a marker of cell-cell contacts. $\mathcal{f}$ Cell Biol 1992; protein is a mark $1511-22$.

29 Mackay CR. T-cell memory: the connection between function, phenotype and migration pathways. Immunol Today tion, phenotype and

30 Salmi M, Jalkanen S. Molecular basis of cell migration into normal and inflamed gut. In: MacDonald TT, ed. Immunology of gastrointestinal disease. Dordrecht: Kluwer Academic, 1992: 151-72. 
31 Pabst R, Binns RM. Heterogeneity of lymphocyte homing physiology: several mechanisms operate in the control of migration to lymphoid and non-lymphoid organs in vivo. Immunol Rev 1989; 108: 83-109.

32 Brandtzaeg P, Halstensen TS, Kett K. Immunopathology of inflammatory bowel disease. In: MacDermott RP, Stenson WF, eds. Inflammatory bowel disease. London: Elsevier, 1992: 95-136

33 Wakefield AJ, Sawyerr AM, Dhillon AP, Pittilo RM, Rowles PM, Lewis AA, et al. Pathogenesis of Crohn's disease: multifocal gastrointestinal infarction. Lancet 191989; ii: 1057-62.

34 Wakefield AJ, Sankey EA, Dhillon AP, Sawyerr AM, More $\mathrm{L}$, Sim R, et al. Granulomatous vasculitis in Crohn's disease. Gastroenterology 1991; 100: 1279-87.

35 Murch SH, Braegger CP, Sessa WC, MacDonald TT. High endothelin-1 immunoreactivity in Crohn's disease and endothelin-1 immunoreactivity in Crohn's disease and
ulcerative colitis. Lancet 1992; 339: 381-5.

36 Berg EL, Robinson MK, Warnock RA, Butcher EC. The human peripheral lymph node vascular addressin is a ligand for LECAM-1, the peripheral lymph node homing receptor. F Cell Biol 1991; 114: 343-9.

37 Davison PM, Bensch K, Karasek MA. Isolation and growth of endothelial cells from the microvessels of the newborn human foreskin in cell culture. $\mathcal{F}$ Invest Dermatol 1980; 75: 316-21.

38 Jackson CJ, Garbett PK, Nissen B, Schrieber L. Binding of human endothelium to Ulex europaeus I-coated Dynabeads: application to the isolation of microvascular endothelium. 7 Cell Sci 1990: 96: 257-62

39 Kubota Y, Kleinman HK, Martin GR, Lawley TJ. Role of laminin and basement membrane in the morphological laminin and basement membrane in the morphological lifferentiation of human endothelial cells in

40 Haraldsen G, Kvale D, Lien B, Brandtzaeg P. Microvascular endothelium from human intestine is constitutively and functionally different from human umbilical vein endothelial cells. Gut 1994; 35 (suppl 4): A32.

41 Haraldsen G, Rugtveit J, Kvale D, Gaudernack G, Brandtzaeg P. Positive immunoselection and primary culture of human intestinal microvascular cells [Abstract]. VIIth International Symposium on the Biology of Vascular Cells. San Diego: November 10-14, 1992.
42 Burgio VL, Zupo S, Roncella S, Zocchi M, Ruco LP, Baroni CD. Characterization of EN4 monoclonal antibody: a reagent with CD31 specificity. Clin Exp Immunol 1994; 96: 170-6.

43 Takahashi K, Sawasaki Y, Goto T, Hata J, Mukai $M$ Cobblestone monolayer cells from human omental adipose tissue are possibly mesothelial, not endothelial. In Vitro Cell Dev Biol 1989; 25: 109-11.

44 Booyse FM, Quarfoot AJ, Chediak J, Stemerman MB Maciag T. Characterization and properties of cultured human von Willebrand umbilical vein endothelial cells. Blood 1981; 58: 788-96.

45 Marks RM, Czerniecki M, Penny R. Human dermal microvascular endothelial cells: an improved method for tissue culture and a description of some singular properties in culture. In Vitro Cell Dev Biol 1985; 21: $627-35$.

46 Ryan US, White LA. Varicose veins as a source of adult human endothelial cells. Tissue Cell 1985; 17: adult

47 Pronk A, Leguit P, Hoynck van Papendrecht AAGM, Hagelen E, van Vroonhoven TJMV, Verbrugh HA. A cobblestone cell isolated from the human omentum; the mesothelial cell; isolation, identification, and growth characteristics. In Vitro Cell Dev Biol Animal 1993; 29: 127-34.

48 Kurtin PJ, Pincus GS. Leukocyte common antigen - a diagnostic discriminant between hematopoietic and nonhematopoietic neoplasms in paraffin sections using monoclonal antibodies. Hum Pathol 1985; 16: 353-65.

49 Falini B, Flenghi L, Pileri S, Gambacorta M, Bigerna B, Durkop $\mathrm{H}$, et al. PG-M1: a new monoclonal antibody directed against a fixative resistant epitope on the macrophage-restricted form of the CD68 molecule. Am F Pathol 1993; 142. 1359-72.

50 Davison PM, Karasek MA. Human dermal microvascular endothelial cells in vitro: effect of cyclic AMP on cellular morphology and proliferation rate. F Cell Physiol 1981; 106: 253-8.

51 Thornton SC, Mueller SN, Levine EM. Human endothelial cells: use of heparin in cloning and long-term serial cultivation. Science 1983; 222: 623-5. 